\title{
UNIVERSITY MANAGEMENT: A FEW PROBLEMATIC THINGS
}

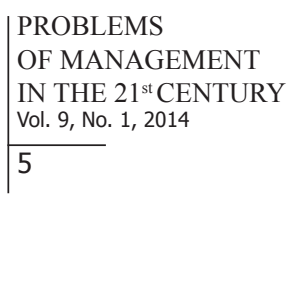

\author{
Vincentas Lamanauskas \\ University of Šiauliai, Lithuania \\ E-mail: v.lamanauskas@ef.su.It
}

University activity and effective functioning is the object of constant discussions. This is taking place in all countries, having university education sector. It is understandable, that the context of every country is different, having individual traits and peculiarities. Lithuania is not an exception. The country's higher education system experiences serious challenges, which are caused both by local socioeconomic changes and international global matters. Labour market dynamism and the changing society require flexible, innovative and creative lifelong learning possibilities. Higher education institutions do not limit themselves with basic specialist preparation, but search possibilities for the specialists and professionals to improve, change their specializations, train their personal abilities and develop high level professional competencies. Thus, continuing teaching (studies) at universities becomes more and more urgent.

It is not sought here to analyse deep, strategic things of university management, but just to draw attention to a few problematic things on the basis of Lithuanian experience and context. Some moments are likely to be urgent not only for Lithuanian universities.

As it is known, for a long time Lithuanian higher education system has been managed "from the top", i.e., by central government. In the Soviet times, the main standard documents used to be prepared centrally, all higher education institutions used to follow the same plans and regulations. On the other hand, trying to achieve higher education was important, seeking to assure a certain position in society. Of course, there used to exist a strict so-called professional orientation system (today fashionably called career designing or career planning), which used to select the pupils. Those, who were doing worse in learning, the pupils of lower abilities, used to be oriented to vocational schools. Over several decades, a rather negative opinion formed about vocational schools. After 1990, having re-established Lithuanian independence, Lithuanian higher education system experienced transformation. It needs to be said, that changes of this system were going the slowest. General education sector was being reformed much faster. Higher education system was changing very slowly. On the other hand, administrative restrictions having not remained, plenty of pretenders, seeking to acquire a higher education diploma, gushed to universities. Over the last $20^{\text {th }}$ century decade, the universities were functioning quite well; big threats were not seen or were not wished to be seen. It was the action of inertia. In fact, Lithuanian universities were developing extensively - the number of students was increasing, there were quite enough of activities, the number of payable places at universities was also rapidly growing. Non budgetary financing of many universities reached almost 50 percent. However, imperceptibly the other tendencies became apparent as well. Professional education sector was changing rapidly. Lithuania allocated big financial resources to change vocational school activity in essence. Meanwhile, the universities began to feel the shortage of students. A great number of factors had an influence on this: big emigration, possibilities to study in foreign country universities, international higher education market participant pressure and so on. Finally, in different ways, the attitude was getting stronger in society, that only abroad one can acquire quality higher education. Since 2000 , the universities consequently started to decrease. 
Vincentas LAMANAUSKAS. University Management: A Few Problematic Things

PROBLEMS

OF MANAGEMENT

IN THE $21^{\text {st }}$ CENTURY Vol. 9, No. 1, 2014

6

To be more precise, the number of the studying has been significantly and purposefully diminishing. One of the goals to keep students and to attract them is the new study programmes. On the one hand, it is a positive thing, seeking to renew oneself, to maintain a proper university level. However, an opposite effect functions here as well. Especially it is distinct in the field of social and humanitarian sciences. Not necessary, in fact, prospectless, but very similar study programmes, having very "high sounding" titles have been started "to cobble", e.g., public administration, personnel management, children's rights pedagogy, sustainable society development and so on. Thus, it is not surprising, that both in the institution and in government layers opinions appeared about the abundance of study programmes. Finally, study programmes became similar in all universities, in fact, because they simply used to be copied and transferred into other institutions after not a big "curricular make -up". However, it is quite understandable, that new study programmes can and have to be created only on the basis of scientific researches and personal competencies. Market demands are not rejected, but are adequately analysed, evaluated and predicted. Simultaneously, active scientific research work, teachers' professional competence development and improvement should take place.

What to do? You can study management at any Lithuanian university. At technological profile university one can study pedagogy, at a health science university - veterinary and so on. An opinion and an aim were getting stronger in government layers to minimize the number of study programmes, because universities are rapidly loosing their authenticity, specificity. Even such a term appeared as study programme profitableness. It is being measured not according to the specialists' demand or other important indicators, but simply according to students' number and more exactly, according to drawn money amount - it doesn't matter if it is personal or state. Simple business and that's all. No money, no students; scientific pedagogical personnel isn't necessary either. It is simply being diminished, instead of directing the most productive teachers into scientific research activity, making for them better conditions to develop scientific researches. Nobody wants to hear about the law of saving the main personnel under crisis conditions. Perhaps such logics is effective in business organizations, however, for universities it doesn't suit. Scientific pedagogical personnel is being formed for a long time. Special competencies are necessary for this, generation continuity. It's a pity, however, in the latter years Lithuanian universities lose their best specialists because of improper managing strategy. Being satisfied with the lowest qualification personnel is a much more dangerous thing. It was already discussed about this (Lamanauskas, 2011).

Side by side there exists a study programme quality evaluation question. On the one hand, it is necessary to evaluate study programme quality. On the other hand, Lithuania is a special country, from this point of view. We are able to adapt ourselves and not necessarily in the most positive meaning. The process is rather simple. International expert group is formed, which evaluates study programme self-analysis, prepared by teacher teams. It is known, that self analysis is a good thing in this meaning, that it allows ourselves to discern relevant problems and to search the ways for solving them. Such an intention cannot be valued in a negative way. Beside various procedure things, responsibility factor becomes the most important. Not only perfectly prepared strategies (very often "paper"), optimal structures, exactly organised and effectively carried out processes determine organizations' activity success, but also concrete people - various level managers' - responsibility (Lamanauskas, 2012). Moreover, all employees should play active roles and participate in managing the company (Inamori, 2012). Thus, practice is very often opposite. Self-analyses are prepared in the way the experts would like them to be, i.e., they, in fact, do not reflect the real situation. To tell the truth, the experts succeed in noticing and fixing some things, however, this, in fact, does not change the situation. The programme is accredited for a certain period and then it is checked again or it is just written the new one with the new title. As it is known, such situation is only maintaining the status, self-deceiving, thinking that everything is alright. However, the essence of self-analysis is to 
find what is not good, to find the effective ways to change, to implement new changes. From

managerial point of view, this field requires exceptional attention.

And the last moment which requires more exhaustive analysis. In Lithuania a tendency is observed, that it is more worth to acquire higher education diploma because of personal prestige than evaluating its real demand. It is not surprising, that after graduating from universities, not a small part of young people continue their studies in vocational schools. They simply seek to acquire a real, marketable profession, just to learn a certain trade. How to value such a situation? Is it normal, that a person, having graduated from a university, cannot find a job, he is practically not desirable in the market. One can think that higher education just gives flexibility to a man, a wider and deeper attitude. On the other hand, what are the studies at university worth, if one has to inevitably go back to vocational school in order to obtain the profession which could allow consolidating one's position in the market? The question is rhetorical, important, urgent. Is such a tendency observed in other countries? What managerial solutions are necessary here? How should the universities change?

It is obvious, that competence is getting stronger between universities - both at the national and international levels. Blind orientation only to a consumer (a student), only to providing service to him, weakens the quality of the studies and of the acquired education as well.

\section{References}

Inamori, K. (2012). Amoeba management: The dynamic management system for rapid market response. New York: Productivity Press.

Lamanauskas, V. (2011). "Makdonaldinis" išsilavinimas: greitai, pigiai ir lengvai, bet neefektyviai [“McDonaldized" Education: in a Fast, Cheap and Easy Way, but Ineffectively]. Švietimas: politika, vadyba, kokybé / Education Policy, Management and Quality, 2 (8), 4-10.

Lamanauskas, V. (2012). Responsibility for Management. Problems of Management in the 21st Century, $5,4-5$.

Received: April 15, 2014

Accepted: April 30, 2014

Vincentas Lamanauskas
PhD., Professor, Siauliai University, Natural Science Education Research Centre, 25-119 P. Višinskio Street, LT- 76351, Siauliai, Lithuania.

E-mail: lamanauskas@lamanauskas.puslapiai.It

Website: http://www.lamanauskas.puslapiai.lt 